\title{
Convict Criminology and Social Justice Advocacy: Toward Radical Change
}

Robert S. Grigsby

\section{INTRODUCTION}

My name is Bob Grigsby, and I am a twenty-year veteran of California's prison system. My prison education includes doing time in San Quentin, Folsom, Soledad and gladiator arenas less known by name but just as educationally impressive. One of the major reasons for sharing my voice with you is to discuss the significance Convict Criminology (CC) has for those who have been, and continue to be, marginalized by the policies and practices of the current criminal justice system long after they have fulfilled their debt to society. As others in the discipline have sought to generate a discussion in journals such as Theoretical Criminology (see Chancer and McLaughlin, 2007) and Criminology \& Public Policy (see Clear, 2010) on what roles criminologists can play to affect change beyond academia, I hope to cultivate and nourish a call for a radical change in how CC currently approaches social justice advocacy and practice.

Personally, as an ex-convict that pursued higher education, I know that the ability to point to our college degrees and the growing list of $\mathrm{CC}$ publications is socially and politically empowering. While I am an ex-convict, I am also a social scientist, criminologist, policy analyst and professional researcher. My professional resume lists my work as a violence suppression specialist, gang intervention counselor, cognitive-behavioral program coordinator, rehabilitation program developer inside and outside prison, and research analyst serving the institutional research and planning department needs for a community college. I have also served numerous community human service agencies and organizations as subject matter expert, policy analyst, advocate, consultant, and educator.

This article seeks to explore how CC can help to build a community of social justice advocates. I will discuss my personal background, the continued growth, acceptance and effectiveness of $\mathrm{CC}$, along with my experience counseling former prisoners in Iowa. From there I advance a call to action in lieu of CC's marginalized public voice. I conclude with a discussion on what the future of CC may look like if those who adopt this perspective make space for a larger role for public engagement. 


\section{CONTINUED GROWTH, ACCEPTANCE AND EFFECTIVENESS OF CC}

As a member of the CC Group, I have witnessed with enthusiasm the continued growth, acceptance and effectiveness of the perspective (Richards and Ross, 2001, 2004; Ross and Richards, 2003; Jones et al., 2009; Ross et al., 2010; Richards et al., 2011) as a platform for change. In pointing to the growth and acceptance of CC first, I am referring to both the book Convict Criminology (Ross and Richards, 2003) and the concept of theoretical criminology from the perspective of a Convict Criminologist.

As people who have been incarcerated our voices and views have not always been heard or understood. There have been moments when a dialogue is attainable, where ideology merges and opportunities are possible to discuss what "works". As prisoners and former prisoners, we have consistently been confronted with "what qualifies you" to speak on such matters. Unfortunately, our experiential understanding of the criminal justice system is not always accepted as legitimate by academics and policy makers.

As felons we have been summarily dismissed as being irrelevant to the process, yet we are the very subjects of observation and scrutiny. There is a deep appreciation for the opportunity $\mathrm{CC}$ offers to those seeking to orchestrate change in the social policy that maintains our current state of criminal justice administration. $\mathrm{CC}$ validates our jailhouse experiential learning degrees, helping to qualify us to speak on such issues related to criminal justice and corrections.

As a former prisoner, I know that our criminal justice system is terribly offensive and sick. Still, our voices are few and our dialogue is fractured in many places. Nevertheless, through our exchange of ideas we must seek to find coordination that directs our efforts to move such a coalition forward. We have a unique responsibility to describe what we have directly observed about the atrocities of prisons and a criminal justice system that is failing miserably. We are a voice that speaks for the many men and women who cannot speak. We are among their representatives and hope. We must speak clearly, with conviction, and as a collective voice if we are to be among their advocates.

In stating this, I have arrived at that point where a more "public voice" and "direct social engagement" is required, where the focus of the discussion centers on seeking to establish a platform for change. While CC has moved 
our voices forward, a more public voice - in face and presence - must seek to bring the discourse out of the dark. We must capture the attention of mainstream society for $\mathrm{CC}$ to become a more effective platform for change. This means we must actively engage society and become proactive changeagents in the public's understanding of crime, criminals, victimization, reentry, reintegration, and social policy practices.

\section{MY EXPERIENCE COUNSELLING FORMER PRISONERS IN IOWA}

I want to share a few observations and a couple of thoughts with regards to my experience researching and interviewing ex-felon individuals and families as they transitioned from prison to communities in Iowa (Richards, 1995; Richards and Jones, 1998, 2004) over the past few months. Such an endeavor provided an opportunity to actively engage with an ever-growing number of men and women who rely on 'hand-outs' and 'volunteers' to assist them with their personal and socio-economic needs for every day living and survival. Much of this engagement centered on performing assistance with locating social services that provide food, clothing and shelter to these marginalized families. However, an equal amount of my time was devoted to listening to the concerns voiced by the men and women concerning their struggles with homelessness, unemployment, drug addiction, mental health, and reintegration into society after years of incarceration.

What I found during my discussions with these viable, capable men and women is an undeniable desire to succeed, to right themselves and their families by changing their current circumstances to reach their personal intentions. Many of the women I talked with shared their distrust of others, their fears of being victimized "again" by those they once trusted, vowing to never allow themselves to be so vulnerable that others could or would take advantage of them or use them. Paradoxically, they expressed these concerns, yet ventured into situations and relationships that have all the elements of them being once more victimized.

Many others voiced their fear, anxiety and apprehension of what the future holds for them, especially for those who are transitioning from prison to the community with little to no resources. Discussion also evolved around the frustrations with managing a "spoiled identity" (Murphy et al., 2010), that of being labeled an ex-felon. Their concerns gravitated to how they are viewed 
by others, which causes them to feel that they somehow have the words "excon" emblazed or tattooed on their forehead, rendering them as worthless, and generating emotions of low self-worth, emptiness, insignificance, and uselessness contaminating their decision-making process.

I also found that some of these men and women were living on the street, in parks or under bridges. They face many roads of uncertainty, with many obstacles and detours to overcome. Many of them are confronted with medical issues, which require professional caregiver involvement to address emotional or psychological pain, severe trauma, or chronic physical disabilities. Most have financial difficulties that contribute to their problems.

The emotional despair these men and women feel continues to be unresolved, long after the circumstances that brought them about have occurred. For most, they still face issues of unemployment, court proceedings and government intrusion into their personal lives, while confronting difficulties with psychological health and instability, which has further jeopardized and alienated their recovery and reintegration. Some suffer from loneliness and alienation, as they cannot learn to trust other people for fear of being victimized again, which may lead to experiencing deeper isolation and depression. Often times, they have shared with me personal histories of family violence and abuse, the emotional pain and suffering of which is so great that some have retreated to a psychological state by which they are unable to function. Some find comfort in medication or street drugs to ease their suffering.

For the men and women I have talked with at length, they are confronted with enormous difficulties in maintaining relationships, parenting, socializing and with continuing employment. Their inability to provide emotional and financial support for themselves and their families has spiraled them into greater hardships. Still, there are others who revealed they are hungry for alternative ways to deal with their current situation, are enthusiastic about developing stronger relationships, and networking with individuals and groups that share experience with their circumstance.

They need mentoring and networks that offer opportunities for hope and opportunities to feel safe, when voicing their feelings and thoughts. Role models offer advising and guidance as they strive to make sense of their lives. Their lives are characterized by paradoxes: they strive for closeness, yet they also fear intimacy and often avoid it; they rebel against control, while at the same time they want direction and structure; although they push 
and test limits imposed on them, they see some limits as a sign of caring; they are not given complete autonomy, but they are often expected to act as though they have control over their own lives; they are typically highly selfcentered, self-conscious, and preoccupied with their own world, yet they are expected to cope with societal demands, and go outside of themselves and expand their horizons often without the pro-social living skills to accomplish it; they are asked to face and accept reality, and at the same time they are tempted by many avenues of escape; and they are exhorted to think of the future, although they have strong urges to live for the moment just to survive. With all these polarities it is easy to understand that transitioning from prison or treatment programs into communities is typically a turbulent and fast-moving period that can be marked by stress, isolation, and despair.

Thus, there is a great need for convicts transitioning from prison to the community to form relationships with mentors who share their common experience. These should be ex-convicts with college degrees that have successfully navigated the transition, and can serve as qualified advisors and counselors, who assist them with reaching their personal and professional goals. Unfortunately, most community reentry programs are heavy on rhetoric and slim on services, and employ people at best that may have good intentions, but very little appreciation of the difficulties their clients face. In fact, we know there are many service program providers who do more damage than good. Yet, we continue to ignore our personal, social, and professional responsibility to change the narrative and commentary of such practice. We must provide realistic solutions for rehabilitating and restoring the lives of individuals, and reintegrating people back into our communities or face our own complicity in their failures.

\section{A CALL TO ACTION}

As social scientists, we must shed the value-free myth that we are to remain neutral that the mainstream in our discipline has invoked to choke us into silence. Our research and our findings must reflect our conclusions in a personal way, endeavoring to place our humanity into our scholarship and emotionally stamp the discourse with our personal approval or negation.

As criminologists, we must become active participants in formulating solutions to the social problems we encounter in our research. We must become change-agents through endeavoring to establish an applied and practical 
criminology that advocates for the development and implementation of sound social policy and practice. We must become activist criminologists, decoders for the public interest, which serve to inform and educate citizens, and thereby provide the impetus for social mobilization within the political domain.

As educators, we must embrace the desires of university students whose motivations are to change the world and who seek to bring passion for change. We must encourage them to challenge the social world and to let no one silence their voice. We must cultivate and nourish students to seek who and what they want to be, not what others require them to be.

As service providers, we must endeavor to ensure that we are providing and performing the services that produce results beneficial to those being served. This includes marshalling our efforts to help prisoners and former prisoners overcome the many barriers and impediments they encounter. We must help the men and women we work with to free themselves from correctional custody.

As citizens, we must study current research as a means to understand what really needs to be accomplished in providing for the safety of our families, our neighborhoods and our communities. We must seek to be all these things, if we want to be effective in our profession and as human beings.

\section{CONVICT CRIMINOLOGY'S PUBLIC VOICE}

As a social scientist, criminologist and an ex-convict, my voice speaks to the need for a different course for our society and our criminal justice philosophy, one that $\mathrm{CC}$ is well suited for - a course of radical change and activism, embodied in the legitimacy and authenticity of criminology that has a public face. I would like to see CC develop and establish an activist collective voice and presence that is more "public". This should be a collective group that socially, politically, and academically challenges what we know to be fraudulent in our present-day approach to criminal justice issues, policy and practice. Regardless of our discipline, specialization or profession, we must collectively voice a common theme: our current criminal justice system does not work. We must continuously emphasize this point in all we say and do.

More "public" means decoding the language of the criminal justice debate, the research literature, the double-speak of politicians and those within our discipline to educate mainstream society so that they can readily 
understand and grasp the deceptiveness of our current criminal justice policies and practice. More "public" means applying a greater emphasis on "public" in our social justice research efforts within criminology.

Academic discourse between student and professor, between colleagues, as well as university institutions may well promote a heightened sense of awareness among these bodies that endeavors to lead to further research, journal articles and debate, but these types of dialogue and dissertation are not reaching the "public" of mainstream America. There are also many advocacy organizations that seek to reform the criminal justice system that are astonished to learn that research literature is available, and has existed for many years, that supports their organization's specific arguments that policy change is necessary and required within the criminal justice domain. They have voiced anger that such knowledge has been "hidden" from their review.

We must make this literature more accessible and understandable for advocates and mainstream America. At the same time, we should address our own writing to the mainstream public audience so that they can grasp the significance of our research findings in a personal way; how it affects them, why it affects them, and what can be accomplished through policy options and alternatives (see Ross and Richards, 2002, 2009).

We must become public social justice advocates that are "explainers" and "interpreters" in educating the public audience, so that they can "touch" the mechanics of the political issues that must be confronted. When doing so, we must become more "public" in face and presence, individually and collectively. Such an endeavor requires an activist collective built on the CC paradigm - one that brings alternative dialogues, experiences, and scholarship to mainstream America with an activist voice and presence. It is time for mainstream America to hear these voices that seek to critically challenge the illusions of the criminal justice system, its administration and crime control policies of the status quo.

\section{CONCLUSION: LOOKING AT THE FUTURE OF CONVICT CRIMINOLOGY}

As a man that survived twenty years behind bars in some of America's worst prisons and who has also been free from the pain of confinement for just as much time, I witnessed prison conditions that prove we are 
not a civilized nation. It is time that people with firsthand knowledge and understanding of our politicized criminal justice system to speak and be heard on the poignant effects of social policy and practice that condones or applauds disproportionate minority confinement, civil and human rights abuses, that accepts prisoner rape, torture and murder, that criminalizes mental illness and chemical addiction, and that excludes and disenfranchises millions in this country. Only through a critical paradigm that does not silence scholarship and voice, censor critical thoughts or questions, seek to ridicule, reject or de-legitimize experience, can such an endeavor succeed in facilitating change of social policy and politics of injustice and inequality.

The very essence of $\mathrm{CC}$ is to use the many experiences of current and former prisoners to create a critical discourse to examine and reveal, not conceal, the prejudicial bias within our criminal justice system and our own traditional criminology practice. We can no longer accept that anything will change if our voices remain silent. As with any endeavor, it begins with the birth of an idea, a notion, of what could or should be. At the moment we are in our infancy, looking at the future and what we will become.

\section{REFERENCES}

Chancer, L. and E. McLaughlin (2007) "Public Criminologies: Diverse Perspectives on Academia and Policy", Theoretical Criminology, 11(2): 155-173.

Clear, T. (2010) "Editorial Introduction to "Public Criminologies"”, Criminology \& Public Policy, 9(4): 721-724.

Jones, R. S., J. I. Ross, S. C. Richards and D. S. Murphy (2009) "The First Dime: A Decade of Convict Criminology", Prison Journal, 89(2): 151-171.

Murphy, D. S., B. Fuleihan, S. C. Richards and R. S. Jones (2010) "The Electronic "Scarlet Letter": Criminal Backgrounding and a Perpetual Spoiled Identity", Journal of Offender Rehabilitation, 50(3): 101-118.

Richards, S. C. (1995) The Structure of Prison Release: An Extended Case Study of Prison Release, Work Release, and Parole, New York: McGraw-Hill.

Richards, S. C. and J. I. Ross (2004) "The New School of Convict Criminology", Journal of Prisoners on Prisons, 13: 11-26.

Richards, S. C. and J. I. Ross (2001) "The New School of Convict Criminology”, Social Justice, 28(1): 177-190.

Richards, S. C., M. Lenza, G. Newbold, R. S. Jones, D. S. Murphy and R. S. Grigsby (2010) "Prison As Seen By Convict Criminologists", in M. Herzog-Evans (ed.), Transnational Criminology Manual (volume 3), Nijmegen (Netherlands): Wolf Legal Publishers, pp. 343-360.

Richards, S. C., J. I. Ross, G. Newbold, M. Lenza, R. S. Jones, D. S. Murphy and R. S. Grigsby (2011) “Convict Criminology: Prisoner Re-entry Policy Recommendations", 
in I. O. Ekunwe and R. S. Jones (eds.), Global Perspectives on Re-entry, Tampere (FI): University of Tampere Press, pp. 198-222.

Ross, J. I., and S. C. Richards (2009) Beyond Bars: Rejoining Society After Prison, New York: Alpha/Penguin Group.

Ross, J. I. and S. C. Richards (2003) Convict Criminology, Belmont (CA): Wadsworth. Ross, J. I. and S. C. Richards (2002) Behind Bars: Surviving Prison, New York: Alpha/ Penguin Group.

Ross, J. I., S. C. Richards, G. Newbold, M. Lenza and R. S. Grigsby (2010) "Convict Criminology", in W. DeKeseredy and M. Dragiewicz (eds.), The Handbook of Critical Criminology, London: Routledge, pp. 160-171.

\section{ABOUT THE AUTHOR}

Bob Grigsby, BA, is an ex-convict and independent researcher and policy analyst who is currently working as the education and social policy director for the Center for Social Justice Policy in the United States. He is a lecturer, as well as a facilitator of workshops and seminars on contemporary issues of crime and criminology. Bob is the web administrator for the Convict Criminology Group, co-authoring a number of articles and book chapters with its members. Contact: bobgrigsby@convictcriminology.org 